Submitted $15^{\text {th }}$ July 2021

Accepted $23^{\text {rd }}$ October 2021

\title{
IMPLEMENTATION OF QUALITY MANAGEMENT BASED ON LOCAL WISDOM ON THE OUTPATIENT SERVICE IN THE SURYA HUSADHA HOSPITAL, NUSA DUA
}

\author{
Komang Maha Intan Ayu Lestari ${ }^{1}$, Ketut Arnaya ${ }^{2}$ \\ Undiknas Graduate School, Denpasar, Bali. Indonesia \\ mahaintan05@gmail.com ${ }^{1}$, ketut.arnaya@gmail.com²
}

\begin{abstract}
This research aimed to observe the implementation of quality management of hospital's health care service and to identified whether the service done by the hospital were related to the local wisdom in its quality management implementation. This research was designed using qualitative descriptive approach which was located in Surya Husadha Hospital, Nusa Dua. The data source in this research was a primary data which was collected through the research informant. The informants in this research were the head of polyclinic, the head of health care service division, health workers, and patients. The data validation testing was done using triangulation. The data were analysed using qualitative descriptive analysis technique. The result of this research showed that the quality management implementation on the health care service through the perspective from service users had been implemented properly, from the medical service to the non-medical service. The service which had been done related to the local wisdom on its implementation, based on Tat Twan Asi. Tat Twam Asi used as a guidance in giving service to the people. And also there were other local wisdoms, which were menyama braya and tri hita karana which consists of parahyangan, pawongan, and palemahan.
\end{abstract}

Keywords: quality management, local wisdom and service

\section{INTRODUCTION}

The successfulness of quality management implementation in overall cannot be separated from local wisdom and culture where the company is located. The function of local wisdom, apart from education development, is also to develop the human resource. Local wisdom is a knowledge source which is done dynamically, developing and is continued by certain population. The certain population is integrated with a comprehension about nature and local culture. Local wisdom is also a foundation in policy making on the local level in medical field, agriculture field, education field, natural resource management and other activities in a population. Culture consists of two components, which are value and belief. Value refers to something which is believed by organization's members in knowing what is right and wrong, while belief refers to a behave on how they supposed to be working in an organization (Tika, 2006).

Quality is a perfection of a service product which obeys the established 
standard. The service quality, which is usually used in evaluating a quality of health care service, refers to five quality dimensions which are responsiveness, reliability, assurance, empathy and tangible. Those five quality dimensions can be used to create a satisfaction (Muninjaya, 2011). In several result of researches, service quality had a relationship between nursing service quality and patient's satisfaction escalation (Widyastuti, 2013).

The implementation of integrated quality management, not only used by manufacture company, but also used by service company which operates in medical field. In this topic, hospitals also need to implement the quality management based on local wisdom. Hospital is one of the facilities which give health care service to the people. Hospital always tries to give the complete and high quality service with several superior services, and also prioritizing patient safety. There are some steps which done by the hospital in order to give a high quality service, such as, upgrading the professional hospital management, giving service through kind and faultless human resource, developing the human resource's qualified skills through continuous internal and external training, upgrading the service which focused on the patient's safety and satisfaction as well as providing modern medical facilities and infrastructure in order to support the health growth in Indonesia.

The development on the medical field in Indonesia, aims to attain a competent people in creating a healthy condition both physically and spiritually. According to that statement, the government had been trying to build a health care service which easy to reach and can be used by all levels of society both from the lower class until the upper class, without differentiates the economy status of someone in getting the fair and equitable health care service.

The fair and equitable service may causes a satisfaction since the people nowadays, are started to be critical in evaluating a service, especially in medical field. The Government Regulation of Republic of Indonesia No. 65 of 2005 concerning The Guideline of Preparation and Implementation of Minimum Service Standard, line I paragraph 6 stated that the implementation of government activities in the region, refers to the Minimum Service Standard (SPM) which will guarantee the community in obtaining good services from the government based on their needs.

With the quality service which based on the local wisdom concept in giving health care service, the nurse is hoped to work carefully and always based on reason. To work carefully does not mean to work hard. Otherwise, it means to work with paying attention to the quality which means to work more wisely using a good system, so the result will be better, but with less effort. The level of health care quality service will be determined by the balance level which happened between the three elements.

\section{THEORETICAL FRAMEWORK The Concept of Quality}

Quality is a full picture of characteristic of a product or service which related with its ability to give needs of satisfaction (American Society of Quality Control). Quality is a 'fitness for use' or the usage compatibility (Juran, 2016). Tappen (2015) explains that quality is an adjustment of the client's wish and suitable with the established standard and also it is an achievement of a desired goal. According to 
Supriono (2002), quality is a level of good or bad of something. Quality can be defined as a level of superior. Therefore, quality is a relative measurement of kindness. Operationally, good quality product is the products which fulfill the customer's expectation. Quality is a sustainable process, dynamic and involving all organization. Quality is each people's responsibility and not only the responsibility of quality department (Assaf, 2009).

\section{Total Quality Management (TQM)}

Total Quality Management (TQM) is a concept of improvement which is done continuously, which involves all elements and employees on the each organization level in order to attain the best quality on all organization aspects through management process. According to Hashmi (2014), TQM is a management philosophy which tries to integrate all organization function (marketing, finance, design, engineering, product, customer service, etc), and focuses to fulfill the consumer's expectation and the aim of organization.

According to Tjiptono and Diana (2015), TQM is an approach in increasing the organization productivity (quantitative performance), increasing quality (decreasing the fault and level of failure), increasing the affectivity on all activities, increasing efficiency (decreasing the resource through productivity escalation), and doing all things correctly in a right way. Dale (2013) defines TQM as a mutual cooperation among all people in an organization and it is linked with the business process to produce a value of product. It is a service which beyond the consumer's needs and expectation.

Moreover, Bhat and Cozzolino (2013) argue that TQM is a strategy and integration of management system to increase the consumer's satisfaction. It prioritizes the involvement from all managers and employees and also it uses quantitative method. Whereas, according to Directorate of Productivity Development or Direktorat Bina Produktivitas (2012) TQM is a management system to increase the quality and productivity with using the quality control in solving the problem. It includes the participation from all employees in order to give satisfaction to the customer.

\section{Health Care Service}

Based on Kasmir (2016), service is the ability of company/person in giving treatment which can give a satisfaction to the customer with the established standard. The ability is showed by their human resource, facility and infrastructure. The other opinion which delivers by Moenir (2016), service is the activity which is done by a person or some people with the foundation of material factor through certain system, procedure and method in order to try to fulfill other people' needs which appropriates to their right. Whereas, in the Law No 25 of 2009 concerning the public service, defines that public service is an activity or activities which happened in order to fulfill the service's needs which is consistent with the laws for each of the citizens and residents for product, service or administrative service which provided by public service provider.

Health care service is each people's right which guaranteed in 1945 Constitution of the Republic of Indonesia, in order to increase the health status, both for personal and overall society. The definition of health care service based on 
Ministry of Health of Republic of Indonesia Year 2009 (Depkes RI) which states in Health Laws about health, is each effort which is done individually or together in an organization to take care and increase health, prevent and heal an illness as well as health recovery, of an individual, family, group as well as citizen.

\section{The Concept of Quality Management of Health Care Service}

Law No 25 of 2009 concerning the public service, defines that public service is an activity or activities which happened in order to fulfill the service's needs which consistent with the laws for each of the citizens and residents for product, service or administrative service which provided by public service provider.

The quality of health care service is a level of service perfection of health care service which consistent with the profession standard and service standard by using resource potential which provided in the hospital or public health center (puskesmas). It is delivered properly, efficiently, and effectively. It is also given securely, and satisfied the norm, ethic, law and social culture with paying attention to the limitation and ability of government, citizen and consumer (Herlambang, 2016).

Bustami (2011) states that the quality of health care service is a level of the fulfillment of needs of citizen or a person to the health care which consistent with the proper profession standard by using the resource properly, efficiently, effectively in the limited ability of government and citizen. It also held securely and satisfied the customer according to the proper norm and ethic.

\section{The Local Wisdom on Service}

Local wisdom is everything as a characteristic of a community which consists of economic aspect, cultural aspect, information and communication technological aspect, ecological aspect, and many more. Another source states that local wisdom consists of crops, art creation, tradition, culture, service, natural resource, human resource and many more which becomes supremacy in a region (Dedidwitagama, 2007). Besides, local wisdom will still educate the citizen throughout the times (Hidayat \& Vidjanarko, 2008). Local wisdom is a custom in a community as a symbol of culture values based on the outcome of local innovation, which can be used maximally and is directed positively in various forms and effort to solve the problem (Supadi, 2009).

A local wisdom is the identity of its community. The identity consists of vision, mission and values in their lives. Those values can be used in the effort to continue life, living together and also as an effort to increase the service based on local wisdom which has a universal meaning. The order (cosmos) in a system will send out the value of beauty that is supported and shaped by an order. The beauty saves much information. Therefore, the interaction patterns among the subsystem variety can be occurred proportionally, in balance and harmoniously (Sulistyo, dkk., 2010).

\section{METHODOLOGY}

This research was designed using qualitative descriptive approach which was located in Surya Husadha Hospital, Nusa Dua. The data source in this research 
was a primary data which was collected through the research informant. The informants in this research were the head of the polyclinic, the head of health care service division, health workers, and patients. The data validation testing was done using triangulation. The data were analyzed using qualitative descriptive analysis technique.

\section{RESULT AND DISCUSSION}

\section{The Implementation of Quality Management of Health Care Service in Surya Husadha Hospital, Nusa Dua}

Referring to the Laws of Republic of Indonesia No 44 of 2009 concerning hospital on line 1 , states that hospital is a health care service intuition which held the health care service personally and faultless which provides patient service, outpatient service and emergency. To give a good quality service, it is important to do a management which manages a system, human resource, facility as well as infrastructure in order to run an integrated service. The quality management of health care service is a level of health care service perfection which is held based on ethical code and established service standard, therefore it creates a satisfaction from each patient (Kemenkes in Muninjaya, 2014).

The service user in Surya Husadha Hospital, Nusa Dua, which was external customer, consists of patient, patient's family, visitor, government, health insurance company, citizen, colleague, non-governmental organization and many more (Muninjaya, 2014). To give a high quality service as delivers by Kasmir (2016) which means, the ability of company/person to give a service that can satisfy the customer with the established standard. The ability is showed by their human resource, facility and infrastructure.

Surya Husadha Hospital, Nusa Dua had been giving a service based on the standard and was able to fulfill the customer's needs with the complete facility. Therefore, it can serve various types of patient with any types of illness and also was able to give recovery to its customer. There are five indicators of service quality, which are empathy, tangible, reliability, responsiveness, and assurance.

1. Empathy is giving a sincere attention and tends to be individually or personally. It is given to the customer with the aims to understand the customer's expectation. A company is wished to have an understanding and knowledge about customer. For instance, understanding the customer's needs specifically and also having a comfortable operational time for the customer. Each of the service activities needs a comprehension and understanding in agreed assumption or importance of a thing which related to the service. The service will run smoothly and qualified if every side which related with the service has empathy in completing or taking care of service (Parasuraman, 2015).

According to the interview result from the informants, the medical team had a quite high empathy feeling based on asking the patient's condition every morning and during they were hospitalized. Medical team also sometimes asked the patients regarding their illness which they felt and willingly provided care based on patient's needs. It was consistent with the empathy dimension which was done by arranging a sustainable training to teach how to give a proper and 
right service, therefore the customer may feel comfortable and respected in the effort of understanding the specific needs of customer (Mardikanto, 2016).

2. Tangible is the ability of a company in showing their existence to the external side. The appearance and ability of facility and infrastructure of company and its surroundings are a real proof of a service which is given by the company. The physical proof of service quality is the real physically actualization form which used by the employee based on its usage which may can help to give a service to the people that want it. Therefore, the people satisfied with the service. It also shows the work performance for the service provided (Parasuraman, 2015).

According to the statement from some of the informants, Surya Husadha Hospital in Nusa Dua had a quite decent building with a complete facility and infrastructure. The medical tools and other supported tools in determining diagnosis and therapy were complete and were able to serve all customer needs. The informants stated that Surya Husadha Hospital in Nusa Dua had a clean environment based on the observation that had been done. This made Surya Husadha Hospital in Nusa Dua became a high standard hospital for the citizen, in giving its service.

3. Reliability is an ability to give promised service immediately, accurately and satisfying. A performance must consistent with the customer's expectation. It means punctuality, the same service to all customers without any mistake, sympathetic behaviour and high accuracy. Every services need a proper form of service which means in giving a service, every employee are hoped to have an ability of knowledge, skill, independence, mastery and high work professionalism. Therefore, the work activity produces a form of satisfied service without any complaint and extreme impression of the service received by the citizen (Parasuraman, 2015).

According to the research which was done, Surya Husadha Hospital in Nusa Dua as a hospital which is located in tourism area, was able to handle patient from foreign countries. Surya Husadha Hospital in Nusa Dua was forced to provide competent medical team and human resource in every field, in order to be able to give a maximum service to the citizen. With the intense activity in Surya Husadha Hospital, Nusa Dua, it forced all team to work faster, but still they received complaints from the service users. The informants stated that, with a great amount of patients that the medical team handled, not all patients got a fast response. This thing had become an issue of the service in Surya Husadha Hospital, Nusa Dua.

Based on the phenomenon above, it was consistent with the research that was done by the previous expert. It explained that the low level of customer satisfaction was found in the reliability dimension, especially about the lack of ability of the health worker in a hospital to give a promised service to the patient immediately, accurately, properly and quickly (Mardikanto, 2016). This phenomenon also showed that the service which was felt/received by patient was lower than the service that expected by the patient. If the customer's expectation is bigger than the reality, therefore the service quality that they 
received is not satisfied them enough and finally creates a customer's dissatisfaction (Tjiptono, 2006).

4. Responsiveness is an ability to help and give a quick and proper service to the customers by giving a clear information. Each employee when gives service, focusing on the service aspect which gives much impact to the behaviour of people who receives the service. Therefore, the ability of comprehension from employee to serve people based on the absorption level, understanding, incompatibility of some services they do not know, is needed. It needs a wise, detailed, fostering, directing and persuading explanation in order to respond all forms of procedure and an established work mechanism in an organization, therefore all services get a positive response (Parasuraman, 2015).

According to the research which was done, Surya Husadha Hospital in Nusa Dua had a medical team who were able to direct the patient as well as the family to use a health insurance in order to simplify the service and funding for the patient and family. Besides, the behaviour of medical team were able to explain in detail about the illness information, therapy as well as others which were needed by the patient while they used the service of Surya Husadha Hospital in Nusa Dua.

5. Assurance means the existence of employee's assurance, such as knowledge, politeness and ability to increase the customer's trust to the company service. It has some components such as communication, credibility, security and politeness. Each service needs the assurance of the given service. The form of assurance of a company is very determined by the insurance from the employee which gives the service. Therefore, the people who receive the service, received it quickly, accurately, easy, smoothly and consistent based on the service quality (Parasuraman, 2015).

According to the interview result, Surya Husadha Hospital in Nusa Dua had a discipline and polite human resource in serving the people. The operation schedules as well as the outpatient room booking were done with using the established system. Therefore, the patient and family just need to wait for the information about the action implementation through the phone. For the polyclinic registration, Surya Husadha Hospital in Nusa Dua had done it by online therefore it would decrease the number of queue. Surya Husadha Hospital in Nusa Dua had a security which was responsible for the incidents which happened in Surya Husadha Hospital, Nusa Dua. The visitor had an established visiting time in order to give comfort to the service user of Surya Husadha Hospital in Nusa Dua. Assurance dimension with the best satisfaction value is determined by the employee with a proper knowledge in answering the patient's questions. This was consistent with Surya Husadha Hospital in Nusa Dua as a hospital with foreign patients which can deliver the information properly to the patient as well as the family (Mardikanto, 2016). 


\section{The Implementation of Local Wisdom in the Application of Quality Management in Surya Husadha Hospital, Nusa Dua}

Local wisdom is a habit and culture in a community which refers to the culture values based on the local innovation result. It can be utilized maximally and directed positively to any kind of forms and as an effort to solve a problem (Supadi, 2009). The local wisdom or culture which is well transformed and combined with the value of character education will create good morality harmonization as well. For instance, there are some local wisdom in Bali which are made as a life guidance. The concepts of life such as manyama braya (everybody are relative), Tat Twam Asi (on the same boat), Tri Hita Karana (three causes of happiness) which are Pariangan (harmony with God), Pawongan (harmony with other human), and Palemahan (harmony with nature). The values of local wisdom need to be preserved as guidance and as the facility for implementing character education in public service in Bali.

Local wisdom is also an important value if we look deeply into the morality contained in there. The public service needs to start applying the local wisdom in their region. Local wisdom is used as a guidance and culture for the employee. The local wisdom which is used as guidance by all workers of Surya Husadha Hospital in Nusa Dua while they are working, is Tat Twam Asi. Tat Twam Asi means "they are you, I am you and every creatures are the same". Therefore, if we help other people, it means we help ourselves as well. In the Hindu philosophy, it explains that Tat Twam Asi is an unlimited teaching of morality, which is identical with the 'humanity' in Pancasila. The concept of humanity in Pancasila, if we really pay attention to it, is a realization of Tat Twam Asi teaching which is found in Weda. Tat Twam Asi is able to be guidance in giving service to the people. That human needs to be aware and implement the sense of togetherness, therefore no matter how heavy the problem which is faced by the patient, it may feel alright.

By understanding and performing the teaching of Tat Twam Asi, the medical team as well as the human resource in Surya Husadha Hospital, Nusa Dua would feel the condition which was felt by the patient and the family. Tat Twam Asi (on the same boat) is a mutual help behavior between the medical team, patient as well as the patient's family. Since the patient and family were in a trouble, it was felt by the medical team too. The nurse recommended the family to use their health insurance in order to ease the cost of treatment in the hospital. The behavior of mutual help which was used as guidance, was able to create a maximum work environment and there was a good relationship between the medical team and the patient as well as the family.

Manyama braya (everybody are relative) means that medical team did not consider the patient's background and still gave a service based on the standard and competency of each profession in order to help saved the patient's live.

Tri Hita Karana (three causes of happiness), which are:

1) Parahyangan (harmony with God): Surya Husadha Hospital in Nusa Dua provided a place for patient and their family to pray based on each religion and belief. According to the research which was done, the hospital gave a chance to the patient and family to pray using a facility to help the patient felt closer to 
God in order to support the healing process and their belief in the given treatment process.

2) Pawongan (harmony with other human): the medical workers were often asking the patient condition and received critic and suggestion which can increase the service in Surya Husadha Hospital, Nusa Dua. Therefore, there was a relationship between all employees and patient as well as patient's family. The friendly attitude with the patient and their family also may increase the trust and closeness in the hospital.

3) Palemahan (harmony with nature): Surya Husadha Hospital in Nusa Dua had provided trash can in every room in order to keep the environment clean. The announcement about keeping an environment clean from smoke and the announcement about protecting the plants around the environment were some of the symbols of local wisdom existence. The patient and their family were participated in taking care of the environment in order to stay clean and neat. Therefore, it gave a secure feeling to the medical team while they did their work and also gave comfort to the patient. The smoking ban in the hospital also gave comfort and helped the healing process of the patient.

\section{CONCLUSION}

The implementation of quality management of health care service in Surya Husadha Hospital, Nusa Dua, Denpasar from the perspective of service user had applied properly, from the medical worker's service until non-medical service. On the indicators of empathy, tangible, reliability, responsiveness and assurance, Surya Husadha Hospital in Nusa Dua was stated that it already had a proper quality management and was able to fulfill the needs of service user. Although, still there were some complaints on the system and the giving of information which was less detailed since the number of patient was quite large.

The service which was done by Surya Husadha Hospital in Nusa Dua related to the local wisdom in the application of health care service was based on Tat Twam Asi. Tat Twam Asi was used as guidance in giving service to the people. Besides, there were other local wisdom, which were menyama braya, tri hita karana yaitu parahyangan, pawongan, and palemahan.

\section{REFERENCES}

Aditama Tjandra Y (2007). Manajemen Administrasi Rumah Sakit. Penerbit Universitas Indonesia. Jakarta

Afriyanti D, Pangestoeti W, Alfiandri (2014). Kualitas Pelayanan Keperawatan di Rumah Sakit Umum Daerah (RSUD) Tanjung Uban Provinsi Kepulauan Riau, Skripsi, Program Ilmu Administrasi Negara Fakultas Ilmu Sosial dan Politik, Universitas Maritim Raja Ali Haji, Tanjungpinang.

Artini, Suarjana I.W,Wijaya I.P.G (2016). Hubungan Penerapan Manajemen Puskesmas dan Komitmen Kerja Dengan Mutu Pelayanan Pengobatan di 
Puskesmas Kabupaten Karangasem Bali, Tesis, PRODI Kesehatan Masyarakat, Universitas Udayana, Denpasar.

Assaf A.F (2009). Mutu Pelayanan Kesehatan Perspektif Internasional. Jakarta: EGC.

Atihuta J.A, Pasinringi S.A, Bahar B (2009). Analisis Faktor Yang Mempengaruhi Kinerja Mutu Pelayanan di RSUD Dr M. Haulussy Ambon

Cahyono U (2012). Kajian Mutu Pelayanan RS Bhineka Bakti Husada yang telah Lulus Akreditasi Ditinjau dari kriteria Malcom Baldrige, Tesis,Universitas Indonesia,Depok.

Depkes (2007). Riset Kesehatan Dasar 2007. Available http://www. Litbang. depkes.go.id/sites/download/BukuLaporan/Lapnas-Risk esdas- 2007/ Indonesia.zip (19 Juli 2017).

Depkes (2008). Upaya Akselerasi Pencapaian Indikator Pembangunan Kesehatan di Indonesia Penurunan AKI, AKB, Gizi Buruk. Available http:// www. depkes.go.id/downloads/MateriRakerkesnas/Panel5/Dir jenBinkesmas.Pdf (15 Juli 2017).

Djoko wijono, (2000). Manajemen Mutu Pelayanan Kesehatan.Surabaya: Airlangga University

Endarwati H.(2012). Upaya Peningkatan Motivasi Dan Keaktifan Berkomunikasi Siswa Dengan Strategi Snowball Throwing. Surakarta: Universitas Sebelas Maret.

Isniati (2012). Kesehatan Modern Dengan Nuansa Budaya, Jurnal Kesehatan Masyarakat. Vol. 7, No. 1.

Kotler dan Keller (2007). Manajemen Pemasaran, Edisi 12, Jilid 1, PT.Indeks, Jakarta.

Moenir, A.S (2010).Manajemen Pelayanan Umum Di Indonesia. Jakarta : Bumi Aksara.

Muninjaya, Gde AA (2011). Manajemen Mutu Pelayanan Kesehatan, Jakarta, EGC

Nursalam.(2011). Proses dan dokumentasi keperawatan, konsep dan praktek .Jakarta : Salemba Medika.

Qolbi (2014). Sistem Manajemen Mutu ISO 9001:2008 Dalam Peningkatan Mutu Pelayanan Dan Kepuasan Pelanggan Di Dinas Kesehatan Kota Tarakan, Jurnal Ilmu Pemerintahan, 2 (4): 3119-3130.

Rahardjo M (2010). Desain Penelitian Kualitatif dan Contoh Proses Penelitian Kualitatif (http:// mudjiarahardjo.com/artikel/208.html?task=vie).24 Agustus 2017.

Sibarani, Robert. 2012. KEARIFAN LOKAL: Hakikat, Peran, dan Metode Tradisi Lisan. Jakarta: Asosiasi Tradisi Lisan (ATL)

Sinambela, Lijan Poltak. Dkk (2011).Reformasi Pelayanan Publik. 
Jakarta:BumiAksara

Sudian T (2011). Hubungan Kepuasan Pasien Terhadap Mutu Pelayanan Kesehatan Di Rumah Sakit Cut Mutia Kabupaten Aceh Utara, Jurnal Kesehatan Masyarakat, Skripsi, PRODI S1 Kesehatan Masyarakat STIKES U'Budiyah.

Sugiyono (2008). Metode Penelitian Kunatitatif Kualitatif dan R\&D. Bandung. Alfabeta.

Sundari M.N.D (2014). Kualitas Pelayanan kesehatan di RSUP Sanglah Denpasar dari Perspektif Pelanggan Internal dan Eksternal,Tesis, Universitas Udayana, Denpasar.

Swarjana I.K (2014). Panduan Penyusunan Proposal Penelitian. Prodi Stikes Bali.Denpasar

Ummah A.R, Supriyanto S (2014). Analisis Mutu Pelayanan Kesehatan Berdasarkan Dimensi Dbholkar diPaviliun Mina Rumah Sakit Siti Khodijah Sepanjang, Jurnal Administrasi Kesehatan Indonesia, 2(1)

Widyastuti A.S (2013). Hubungan Antara Mutu Pelayanan Tenaga Perawat Dengan Tingkat Kepuasan Pasien Diruang Rawat Inap Puskesmas Wonosegoro I Boyolali, Skripsi, Program Studi S1 Keperawatan, Universitas Muhammadiyah Surakarta, Boyolali.

Wiyono, Djoko. (2000). Manajemen Mutu Pelayanan Kesehatan, Teori, Strategi dan Aplikasi. Surabaya : Airlangga University Press.

Zakiyudin, Ais. 2016. Sistem Informasi Manajemen. Jakarta: Penerbit Mitra Wacana Medi. 